\title{
Student's Perception of Academic Courses in B.Sc. Nursing at Nursing Campus Maharajgunj, Kathmandu Ajanta Singh*
}

Nursing Campus Maharajgunj, Kathmandu

${ }^{1}$ Lecturer, Nursing Campus Maharajgunj, Kathmandu

\begin{abstract}
Background and Objectives: Nursing is practice oriented education where knowledge, skill and attitudes are taught simultaneously. Learning environment, resources and supportive measures are the important factors for determining academic success and learning. The objective of this study was to find out the perception of the B.Sc. level pass out students towards the academic course provided to them.

Material and Methods: Descriptive study was conducted to find out the perception of the students. Self-administered questionnaire were used to collect information regarding demographic information of the respondents and their perceptions were viewed in terms of learning environment, resources and supportive measures. Descriptive statistics was used to analyze the data and findings were presented in tables in terms of frequency and percentage.

Results: Almost all (93\%) of the respondents were living in Kathmandu permanently, only $41 \%$ of them had nursing as their first professional career. Most of them (82.8\%) responded that the course content were enough. More than half of the respondent (58.6\%) suggested adding more content on FP/MCH/ Immunization. Very few 13\% felt that courses like health teaching (13.8\%) in first year, nail care $(6.9 \%)$ and bed making $(10.3 \%)$ seems unnecessary. Very few that were only $31 \%$ of teachers met the student's expectation and were not satisfied with the teaching strategy of most of the teachers. Senior students were the most (56.7\%) helping characters in their learning period. More than ninety percent (93\%) had their plan to go abroad for job/study and the choice of country was USA (41.3\%).
\end{abstract}

Conclusion: Based on the findings it was concluded that certain changes in the course is necessary and teaching strategies has to be modified for better results.

Kev words: Academic Course, Nursing Students and Perception.

INTRODUCTION

The learning climate has been found to be significant in determining student's academic achievement and learning [1]. The quality of an educational environment is indicative of the effectiveness of an educational program 
on student learning motivation and learning outcome. Nursing as a profession is currently compelled to address the challenges posed by globalization and to respond by forming international alliances that will facilitate knowledge sharing in order to improve human health. In nursing programme the main objective is to produce nursing graduates who can provide comprehensive care and treatment to the community [2]. The critical components of a learning environment are not restricted to student teacher communication and activities but include appropriate physical structure and services which reflects curriculum quality, teaching and learning as well as support for student outcomes as practioners. A systemic approach to designing a learning environment can lead to positive outcomes for graduates [1].

Student's satisfaction is an important element of the effectiveness of clinical placement but there is little consensus in the literature as to the preferred model of clinical experiences for undergraduate nursing students. Learning environment has a significant role in determining student's academic achievement and learning [3]. It is essential for managers to make a greater effort to create an appropriate educational environment in order to provide and maintain high quality learning environment for students. Supportive learning environment are essential for medical education and will increase learning environment perceptions. Student's feedback is critical components of teacher learner cycle, however limited research are conducted to evaluate student's perceptions $[1,3]$.

Starting from the basic first year; learning about all basic patient care, systemic diseases related nursing care in second year, care related to gynecological and obstetric nursing care and finally management and leadership including teaching learning activities in the final fourth year [2]. Coming up to the end of final year they were be able to analyze the academic course and express their views on it. Determining the perception helps to identify the positive and areas to be improved on the basis of student's felt need. The objective of this study was to find out the perception of the B.Sc. level students towards the academic course provided to them. The findings will help in reviewing the curriculums regarding the course content and the teaching learning strategies for better learning.

\section{MATERIAL AND METHODS}

\section{Study Design}

This descriptive cross-sectional study was conducted in Nursing Campus Maharajgunj during the period of November/ December 2015. All the B.Sc. Nursing students who had completed their final year examination of fourth year were included in the study. Census method was used to collect data among the total 30 students; all the students were included in the study. One respondent who was absent at the time of data collection was excluded. An approval letter was taken from the institution and informed consent was taken from each respondent prior to the data collection by explaining the objectives of the study.

\section{Data Collection and Processing}

Students in a class were given a brief description of the study. Semi structured selfadministered questionnaire were distributed to each participant to choose the answers and express their own views. Data were collected by the researcher herself. After giving thanks 
collected information were checked for the completeness and accuracy. The collected data were entered in Microsoft excel and were analyzed using simple descriptive statistics and presented in tables in frequency and percentage. The questionnaire consists of two parts. Part I contained information regarding demographic variables and part II contained information regarding their perceptions on course content, learning environment and their future plans.

\section{RESULTS}

Table 1: Characteristics of the Respondents

\begin{tabular}{|c|c|c|c|}
\hline \multicolumn{4}{|c|}{$\begin{array}{l}\text { Table 1: Characteristics of the respondents } \\
\qquad(\mathrm{N}=29)\end{array}$} \\
\hline Variables & Responses & Number & $\begin{array}{c}\text { Percentage } \\
\text { (\%) }\end{array}$ \\
\hline \multirow[t]{2}{*}{ Age } & $21-22$ & 8 & 27.5 \\
\hline & $23-24$ & 21 & 72.5 \\
\hline \multirow[t]{2}{*}{ Residence } & $\begin{array}{c}\text { Inside } \\
\text { Kathmandu } \\
\text { valley }\end{array}$ & 27 & 93 \\
\hline & $\begin{array}{l}\text { Outside } \\
\text { valley }\end{array}$ & 2 & 7 \\
\hline \multirow{3}{*}{$\begin{array}{l}\text { Aim was to } \\
\text { become }\end{array}$} & Doctor & 15 & 54.9 \\
\hline & Nurse & 12 & 41.2 \\
\hline & Actress & 2 & 6.9 \\
\hline \multirow{3}{*}{$\begin{array}{l}\text { Immediate } \\
\text { plan }\end{array}$} & Find a job & 23 & 79.3 \\
\hline & $\begin{array}{l}\text { Further } \\
\text { study }\end{array}$ & 4 & 13.8 \\
\hline & Go abroad & 2 & 6.9 \\
\hline
\end{tabular}

Most of (72.5\%) respondents were between the age of 23 -24 age and maximum of them were residing within Kathmandu valley. More than half $(54.9 \%)$ of the respondent had their aim to be a doctor and now after completing their nursing course their plan was to find a job (79.3\%) as shown in table 1.

\section{Table 2: View of Respondents towards Course Content}

Table 2 shows that most of $(82.8 \%)$ of respondent thought that the course provided was enough. Similarly most of them felt the course that needs to be added is on Family Planning/Maternal and Child Health (FP/MCH) and immunization (58.6\%). It also shows that health teaching in the first year is not necessary or not useful (13.8\%) but $69 \%$ of them responded that all courses are equally important.

\begin{tabular}{|c|c|c|c|}
\hline \multicolumn{4}{|c|}{$\begin{array}{l}\text { Table 2: View of Respondents towards Course Content } \\
\qquad(\mathrm{N}=29)\end{array}$} \\
\hline Variables & Responses & Number & $\begin{array}{c}\text { Percentage } \\
(\%)\end{array}$ \\
\hline \multirow{2}{*}{$\begin{array}{l}\text { Course } \\
\text { content } \\
\text { enough }\end{array}$} & Yes & 24 & 82.8 \\
\hline & No & 5 & 17.2 \\
\hline \multirow{3}{*}{$\begin{array}{c}\text { Courses } \\
\text { needed to be } \\
\text { added }\end{array}$} & $\begin{array}{c}\mathrm{FP} / \mathrm{MCH} / \\
\text { Immunization }\end{array}$ & 17 & 58.6 \\
\hline & $\begin{array}{l}\text { Teaching } \\
\text { learning }\end{array}$ & 10 & 34.5 \\
\hline & Social science & 2 & 6.9 \\
\hline \multirow[t]{4}{*}{$\begin{array}{l}\text { Unnecessary } \\
\text { courses }\end{array}$} & $\begin{array}{c}\text { All are } \\
\text { necessary }\end{array}$ & 20 & 69 \\
\hline & $\begin{array}{l}\text { Health } \\
\text { teaching in } \\
\text { first year }\end{array}$ & 4 & 13.8 \\
\hline & Bed making & 3 & 10.3 \\
\hline & Nail care & 2 & 6.9 \\
\hline
\end{tabular}

Table 3: Respondents View toward Educational Activities

Regarding the educational activities and academic environment most of them (69\%) of the respondent stated that they are not satisfied with the teachers, only $17.2 \%$ of respondent said that the provided educational materials were adequate as shown in table 3. 


\begin{tabular}{|c|c|c|c|}
\hline Variables & Responses & Number & $\begin{array}{c}\text { Percentage } \\
\text { (\%) }\end{array}$ \\
\hline \multirow{2}{*}{$\begin{array}{c}\text { Teachers met } \\
\text { their } \\
\text { expectation }\end{array}$} & Yes & 9 & 31 \\
\hline & No & 20 & 69 \\
\hline \multirow{2}{*}{$\begin{array}{l}\text { Teaching } \\
\text { method used }\end{array}$} & Appropriate & 4 & 13.6 \\
\hline & $\begin{array}{c}\text { Not } \\
\text { appropriate }\end{array}$ & 25 & 86.4 \\
\hline \multirow{2}{*}{$\begin{array}{l}\text { Educational } \\
\text { resources }\end{array}$} & Adequate & 5 & 17.2 \\
\hline & $\begin{array}{c}\text { Not } \\
\text { adequate }\end{array}$ & 24 & 82.8 \\
\hline \multirow{2}{*}{$\begin{array}{c}\text { College } \\
\text { environment } \\
\text { inducive to } \\
\text { learning }\end{array}$} & Yes & 12 & 41.4 \\
\hline & No & 17 & 58.6 \\
\hline \multirow{2}{*}{$\begin{array}{c}\text { Competent } \\
\text { teachers }\end{array}$} & Yes & 16 & 54.2 \\
\hline & No & 13 & 44.8 \\
\hline \multirow{3}{*}{$\begin{array}{l}\text { Most helpful } \\
\text { person }\end{array}$} & Seniors & 17 & 56.7 \\
\hline & Friends & 9 & 31 \\
\hline & Teachers & 3 & 10.3 \\
\hline
\end{tabular}

Table 4: Responses on Future Plan

\begin{tabular}{|c|c|c|c|}
\hline \multicolumn{4}{|c|}{ Table 4: Responses on Future Plan } \\
N=29 \\
\hline Variables & Responses & Number & $\begin{array}{c}\text { Percentage } \\
\text { (\%) }\end{array}$ \\
\hline $\begin{array}{c}\text { Plan to go } \\
\text { abroad }\end{array}$ & Yes & 27 & 93 \\
\cline { 2 - 4 } & No & 2 & 7 \\
\hline $\begin{array}{c}\text { Choice of } \\
\text { foreign } \\
\text { country }\end{array}$ & USA & 12 & 44.4 \\
\cline { 2 - 4 } & Canstralia & 8 & 29.6 \\
\cline { 2 - 4 } & UK & 3 & 14.8 \\
\hline \multirow{2}{*}{$\begin{array}{c}\text { Purpose of } \\
\text { going } \\
\text { abroad }\end{array}$} & For job & 20 & 74 \\
\cline { 2 - 4 } & For higher & 9 & 26 \\
\hline
\end{tabular}

Regarding future plans of the respondent 93\% had plan to go abroad and the first choice of the country was USA i.e. $44.4 \%$ followed by Australia $29.6 \%$ and the main purpose of going abroad was to find a job and earn money as shown in table 4.

\section{DISCUSSION}

Nursing profession has a base in home, coexistent with the first mother who performed for her little ones, all those services which made it possible for them to live and thrive. Woman's role and status, religious values, war, societal attitude and visionary nursing leadership has influenced nursing and nursing education from the ancient period till now [4]. As per the information of Kathmandu metropolitan it is the most densely populated city of Nepal covering 20\% of total population and everybody wants to be in Kathmandu [5], similar to that most of the respondents were from Kathmandu valley. Regarding choice of profession more than half of the nursing students had first choice as doctor which shows that nursing was their second option, only few of them were heartily wanted to become a nurse.

Nursing profession which needs heart to heal and hands to care than cure; if not eternally motivated then can the consumer be satisfied with their work, from consumer news and business channel found that nursing as carrier is in the sixth position [6]. Similarly medical courses are the fourth choice for students who have completed higher secondary education. Regarding the course in the curriculum most of the respondents were satisfied. They said that content regarding $\mathrm{MCH}$ and immunization was not adequate, further modification may be needed to add more content in it. 
Contents like bed making and nail care need to be reviewed as per the respondents but curriculum of Indian Nursing Council and Nepal Nursing Council both strongly supports in incorporating the courses [7]. About 80\% of those receiving permission from foreign affairs actually go on to study abroad with the majority of applicants for this year opting for Japan, Australia the US, India and Malaysia. Nepal has been an important growth market in recent years, it was one of the top three fastest growing market for Australia in 2014 and the second fastest growing for Japan in 2013 [8], but this study showed that their first choice of country for going abroad was USA, it may be due to good salary, strong cultural fit, flexible hours, manageable expectations and practice with full scope of license. The purpose of going abroad was found to be for work, in a study migration among nurses is mostly for the job to fulfill their own need or their family's materials desires and about uplifting their social status [9].

B.Sc. Nursing curriculum has been justified as bringing Nepali nurses training up to International training standard but with no posts in Nepal created for B.Sc. Nursing graduates, these recent developments ignore Nepal's domestic health care requirements. People who have family members, friends or relatives abroad are proud of it and this is particularly evident within middle class social circles in Nepal.

\section{CONCLUSION}

It is essential for faculty members and course managers to make more effort towards observing principles of instructional designs to create an appropriate educational environment in order to provide a better learning environment with more facilities and supportive systems for the students. Timely changes in the curriculum content is necessary, creation of post for B.Sc. Nursing graduates has become too late so that they will fulfill the domestic health care personnel requirement than planning to go abroad.

\section{LIMITATION}

The limitation was the limited sample size and the respondents were from only one nursing campus so cannot be generalized. There are also limited literatures to support the study findings.

\section{ACKNOWLEDGEMENT}

Author is greatly indebted and wishes the heartfelt thanks to B. Sc. Nursing students (8th Batch) of Nursing Campus Maharajgunj for their support and cooperation and equally the institution Nursing Campus Maharajgunj for providing the platform.

\section{AUTHOR'S CONTRIBUTION}

AJ- is herself a researcher and has done all the work solely.

SOURCE OF SUPPORT: None

CONFLICT OF INTEREST: Author declares that there is no conflict of interest.

\section{REFERENCES}

1. Bakhshi $\mathrm{H}$, Abazari F, and Bakhshialiabad MH. Nursing Students' Perceptions of their Educational Environment Based on DREEM Model in an Iranian University Malaysian Journal of Medical Sciences; MJMS. 2013; 20(4): 56-63.

2. Curriculum for Generic Bachelor of Science in Nursing Programme. Tribhuvan University, Institute of Medicine, Maharajgunj Nursing Campus, Kathmandu Nepal, December 2008.

3. Bakhshialiabad H, Bakshi M, Hassanshahi G. Students Perception of the Academic Learning 
Environment in Seven Medical Sciences Courses Based on DREEM Advance Medical Education Practice 2015;(7) 23; 6:195-203. Doi 10.2147/AMEP.S60570.e retrieved on 16 February 2016.

4. TuladharK, Shrestha NM, and ShresthaS. Fundamentals of Nursing, Health Learning Material Centre, Institute of Medicine, Tribhuvan University2009.

5. World Population Review.com/worldcities/Kathmandu-population/4 https://www.citypopulation.de/php/nepalkathmanduvalley.php 2016

6. OsterlandA. 2016 www.cnbc.com. Retrieved on 30th May 2016

7. Cunepal.com/professional-courses-Nepal/ Retrieved on 30th May 2016.

8. Clark N. World Education News and Reviews, Educations in Nepal 2013. Published on March 1Retrieved on 30th May 2015.

9. Adhikari R. Aspiration to Dream Trap Nurse Education in Nepal and Nepali Nurse Migration to the UK 2010. Retrieved from http://www.era.lib.ed.ac.uk/bitstream/handle /1842/6199/Adhikari.pdf sequence $=6$ on 16th May 2015.

Correspondence to: Ms. Ajanta Singh

Lecturer

Nursing Campus Maharajgunj

Tribhuvan University

Institute of Medicine, Nepal

Email: ajanta2034@hotmail.com 